\title{
ANALISIS SISTEM INFORMASI AKUNTANSI PENERIMAAN BIAYA TAGIHAN PEMAKAIAN AIR BERSIH PADA PERUSAHAAN DAERAH AIR MINUM (PDAM) TIRTAULI KOTA PEMATANGSIANTAR
}

\author{
Claudya Pandiangan ${ }^{\bowtie}$, Dimita H. P. Purba, Jamaluddin, Mulatua P. Silalahi \\ Universitas Methodist Indonesia, Medan, Indonesia \\ Email: claudyapandiangan9912@gmail.com
}

DOI: https://doi.org/10.46880/methoda.Vol11No3.pp185-193

\begin{abstract}
This study aims to find out how the accounting information system for billing receipts is carried out at PDAM Tirtauli. The method used in this research is using descriptive qualitative research with data collection methods by observation and documentation. Based on the results of this study, it was found that the Accounting Information System from the receipt of clean water usage bills at PDAM Tirtauli, Pematangsiantar City was categorized as good, because the system used was clear and structured. However, the company is still experiencing problems in the Accounting Information System from the receipt of billing fees. These obstacles, such as in the Accounting Information System for receiving billing fees, there are still customers who are in arrears. Furthermore, the Accounting Information System depends on the network. So, network errors can also occur, so that it can interfere with the work of the system on the PDAM. Efforts made by PDAM are to collect customer arrears that have not been paid, and if the payment has not been made for more than 3 months, PDAM Tirtauli will terminate the customer's water line.

Keyword: Receipt Accounting Information System, Bill Cost, PDAM Tirtauli.
\end{abstract}

\begin{abstract}
ABSTRAK
Penelitian ini bertujuan untuk mengetahui bagaimana sistem informasi akuntansi penerimaan tagihan yang dilakukan pada PDAM Tirtauli. Metode yang digunakan dalam penelitian ini adalah menggunakan penelitian kualitatif deskriptif dengan metode pengumpulan data dengan observasi dan dokumentasi. Berdasarkan hasil penelitian ini didapatkan bahwa Sistem Informasi Akuntansi dari penerimaan tagihan penggunaan air bersih pada PDAM Tirtauli Kota Pematangsiantar dikategorikan baik, karena sistem yang digunakan sudah jelas dan terstruktur. Namun perusahaan masih mengalami kendala dalam Sistem Informasi Akuntansi dari penerimaan biaya penagihan. Kendala tersebut, seperti pada Sistem Informasi Akuntansi penerimaan biaya penagihan masih terdapat pelanggan yang menunggak. Selanjutnya Sistem Informasi Akuntansi bergantung pada jaringan. Sehingga dapat juga terjadi kesalahan jaringan, sehingga dapat mengganggu kerja sistem pada PDAM. Upaya yang dilakukan PDAM adalah menagih tunggakan pelanggan yang belum dibayar, dan jika pembayaran tidak dilakukan lebih dari 3 bulan, PDAM Tirtauli akan melakukan pemutusan saluran air pelanggan.

Kata Kunci: Sistem Informasi Akuntansi Penerimaan, Tagihan Biaya, PDAM Tirtauli.
\end{abstract}

\section{PENDAHULUAN}

Perkembangan dunia usaha yang semakin luas saat ini menuntut adanya perkembangan sistem akuntansi baru untuk memenuhi kebutuhan informasi yang lebih baik. Peran dari sistem informasi terhadap kemajuan organisasi sudah tidak diragukan lagi. Dengan dukungan sistem informasi yang baik maka sebuah 
perusahaan akan memiliki berbagai keunggulan kompetitif, sehingga mampu bersaing dengan perusahaan lain. Informasi adalah data yang sudah mengalami pemrosesan sedemikian rupa sehingga dapat digunakan oleh penggunanya dalam membuat keputusan. Adanya sistem informasi yang baik akan menghasilkan informasi yang sesuai dengan kebutuhan. Informasi yang baik merupakan informasi yang dapat disajikan tepat pada waktunya, bermanfaat dan dapat diandalkan.

Salah satu sistem informasi yang penting dalam suatu perusahaan yaitu sistem informasi akuntansi. Sistem informasi akuntansi (SIA) adalah suatu komponen yang mengumpulkan, menggolongkan, mengolah, menganalisa, dan mengkombinasikan informasi keuangan yang relevan untuk pengambilan keputusan pihakpihak luar (seperti pemerintah, masyarakat, investor, dan kreditor) pihak-pihak dalam (terutama manajemen). Sistem Informasi Akuntansi dapat dikatakan sebagai prosedur pencatatan dan melaporkan berbagai informasi yang berkaitan dengan keuangan suatu perusahaan. Selain itu sistem informasi juga berfungsi untuk menyediakan pengendalian yang memadai untuk menjaga aset-aset perusahaan. Oleh karena itu penerapan sistem informasi akuntansi yang efektif dalam suatu perusahaan akan memberikan banyak manfaat bagi perusahaan dan manajemen dalam menjalankan usahanya.

Sistem yang baik akan mengurangi risiko kesalahan saat memproses transaksi dalam jumlah kecil maupun jumlah besar dan transaksi berulang. Misalnya, memungut biaya dari pelanggan ke perusahaan setiap hari. Akuntansi digunakan untuk mencatat transaksi yang berulang-ulang tersebut dan kemudian menghasilkan output berupa laporan keuangan. Sistem adalah kumpulan elemen yang saling berkaitan dan bekerja sama dalam melakukan kegiatan utuk mencapai suatu tujuan (Sujarweni V. Wiratna, 2015).

Pada perusahaan yang diteliti juga menggunakan sistem informasi akuntansi. Sistem informasi akuntansi dalam penerimaan biaya tagihan yang digunakan adalah sistem Komputer Akuntansi (SISKA). Fungsi dari
Sistem Komputer Akuntansi (SISKA) adalah untuk melihat laporan pendapatan setiap bulannya dan juga untuk melihat tagihan pelanggan yang menunggak. Tagihan adalah kewajiban yang harus dibayar pelanggan untuk penggunaan layanan atau fasilitas tertentu, termasuk biaya manajemen, denda, bunga, dan biaya lainnya (jika ada). Penggunaan sistem informasi akuntansi di perusahaan dapat meningkatkan efisiensi dalam menampilkan biaya penagihan. Tetapi pada perusahaan yang diteli juga pernah terjadi kesalahan dalam penginputan data penerimaan biaya tagihan pelanggan. Hal itu disebabkan oleh human error. Kadang kala masalah pada perusahaan di bagian sistem informasi akuntansinya juga tergantung pada jaringan.

Mengingat pentingnya penerimaan biaya tagihan rekening air dalam menunjang aktivitas operasional perusahaan, maka peneliti melakukan analisis sistem informasi akuntansi penerimaan biaya tagihan pemakaian air bersih pada Perusahaan Daerah Air Minum (PDAM) Tirtauli Kota Pematangsiantar.

\section{TINJAUAN PUSTAKA}

\section{Sistem Informasi Akuntansi}

Informasi adalah sekumpulan data atau fakta yang diorganisasi atau diolah dengan cara tertentu sehingga mempunyai arti bagi penerima (Anggraeni, 2017). Akuntansi adalah proses dari transaksi yang dibuktikan dengan faktur, lalu dari transaksi dibuat jurnal, buku besar, neraca lajur, kemudian akan menghasilkan informasi dalam bentuk laporan keuangan yang digunakan pihak-pihak tertentu (Sujarweni V. Wiratna, 2015).

Sistem Informasi adalah sebuah rangkaian prosedur formal dimana data dikelompokkan, diproses menjadi informasi, dan didistribusikan kepada pemakai (Kadir Abdul, 2014). Sistem informasi akuntansi adalah sebagai kumpulan yang terintegrasi dari sub-sub sistem atau komponen baik fisik maupun nonfisik yang saling berhubungan dan bekerja satu sama lain untuk mengolah data transaksi yang berkaitan dengan masalah keuangan menjadi informasi keuangan (Susanto Azhar, 2017). 
Sistem Akuntansi adalah organisasi formulir, catatan, dan laporan yang dikoordinasi sedemikian rupa untuk menyediakan informasi keuangan yang dibutuhkan oleh manajemen guna memudahkan pengelolaan perusahaan (Mulyadi, 2016b). Sistem informasi akuntansi adalah sebuah sistem yang memproses data dan transaksi guna menghasilkan informasi yang bermanfaat untuk merencanakan, mengendalikan, dan mengoperasikan bisnis (Krismaji, 2015). Diana Anastasia \& Setiawati, (2011), berdasarkan definisi sistem informasi akuntansi maka manfaat sistem informasi akuntansi tersebut adalah sebagai pengolah transaksi (transaction processing) dan pengolah informasi (information processing).

Susanto Azhar, (2013) menyatakan fungsi sistem informasi akuntansi adalah mendukung aktivitas sehari-hari perusahaan dan proses pengambilan keputuan serta membantu dalam memenuhi tanggung jawab pengelolaan perusahaan.

Romney, (2015) menyatakan bahwa, sistem informasi akuntansi terdiri atas lima komponen, yaitu pengguna (user), prosedur (procedure), data, perangkat lunak (software) dan infrastruktur teknologi informasi (technology).

\section{Tagihan}

Tagihan adalah sejumlah kewajiban yang harus ditanggung nasabah atas penggunaan layanan dan fasilitas tertentu. Adapun prosedur penagihan secara terperinci yang dikemukakan oleh Mulyadi, (2013) dalam bukunya "Sistem Akuntansi" adalah sebagai berikut:

1. Bagian piutang memberikan daftar piutang yang sudah saatnya ditagih kepada bagian penagihan.

2. Bagian penagihan mengirimkan penagih, yang merupakan karyawan perusahaan, untuk melakukan penagihan kepada debitur.

3. Bagian penagihan menerima cek atas nama dan surat pemberitahuan dari debitur.

4. Bagian penagihan menyerahkan cek kepada bagian kasa.

5. Bagian kasa menyetorkan cek ke bank, setelah cek tersebut dilakukan oleh pejabat yang berwenang.
6. Bank perusahaan melakukan clearing atas cek tersebut ke bank debitur.

\section{Akuntansi Piutang}

Piutang merupakan salah satu unsur dari aktiva lancar dalam neraca perusahaan yang timbul akibat adanya penjualan barang dan jasa atau pemberian kredit terhadap debitur yang pembayaran pada umumnya diberikan dalam tempo 30 hari (tiga puluh hari) sampai dengan 90 hari (sembilan puluh hari). Ciri-ciri akuntansi piutang adalah adanya nilai dan tanggal jatuh tempo, serta adanya bunga yang berlaku.

\section{Flowchart}

Flowchart adalah teknik analitis yang digunakan untuk menggambarkan beberapa aspek dari sistem informasi dengan cara yang jelas, ringkas, dan logis dari awal hingga akhir. Berikut ini merupakan flowchat penerimaan kass seperti yang ditunjukkan pada gambar 1 berikut:

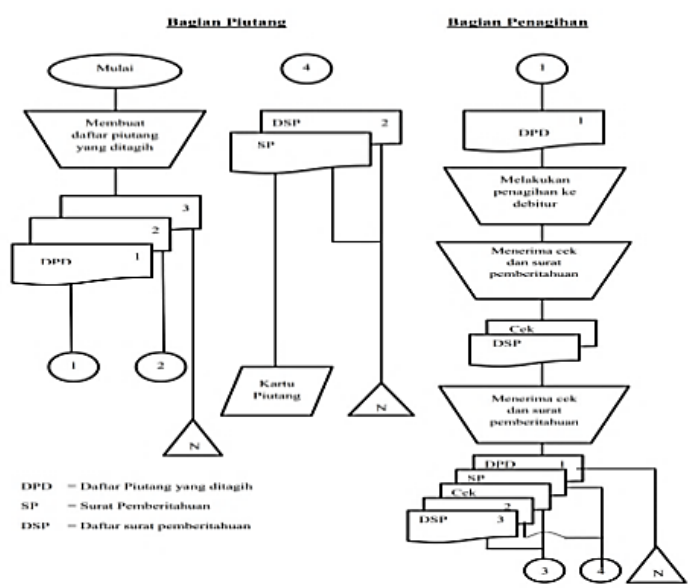

Sumber: (Romney \& Steinbart, 2018)

Gambar 1. Flowchart Penerimaan Kas

Dari flowchart penerimaan kas dari piutang pada gambar dapat dijelaskan prosedur penerimaan kas dari piutang yaitu bagian piutang membuat daftar piutang yang ditagih (DPD) sebanyak 3 lembar: lembar pertama diserahkan kebagian penagihan, lembar kedua diserahkan kepada bagian kasa, lembar ketiga diarsipkan. Kemudian bagian penagihan melakukan penagihan ke debitur atas daftar piutang yang ditagih (DPD) kemudian menerima cek dan surat pemberitahuan (SP). Bagian ini akan membuat 2 lembar daftar surat pemebritahuan (DSP) : DSP lembar pertama 
akan dikirimkan pada bagian kasa beserta cek, DSP lembar kedua dan SP akan dikirimkan pada bagian piutang dan DPD akan diarsipkan. Setelah itu, bagian piutang akan mencatat transaksi pelunasan piutang kedalam kartu piutang berdasarkan DPD dan DSP yang diterima dari bagian penagihan.

\section{Penelitian Terdahulu}

Penelitian sejenis yang telah dilakukan oleh penelitian lain yang menjadi dasar penulis dalam melakukan analisis sistem informasi akuntansi penerimaan biaya tagihan pemakaian air bersih pada Perusahaan Daerah Air Minum (PDAM) Tirtauli Kota Pematangsiantar diantaranya penelitian analisis sistem informasi akuntansi penerimaan dan pengeluaran kas guna efektivitas pengendalian intern pada PDAM Tirta Dharma Parabaya Kabupaten Madiun (Arisqua, Isharijadi, \& Wijaya, 2017), penelitian tentang evaluasi penerapan sistem informasi akuntansi atas pendapatan sewa kamar hotel secara online pada grand sakura hotel medan (Sinambela, Purba, \& Jamaluddin, 2020) dan pada penelitian analisis sistem informasi akuntansi penerimaan kas jasa rawat inap pada RSUD dr. Saiful Anwar Malang (Hasanah, 2013)

\section{METODE PENELITIAN}

Jenis data yang digunakan dalam penyusunan penelitian ini adalah deskriptif kualitatif. Pada penelitian ini dimaksudkan untuk memperoleh informasi mengenai pembayaran biaya tagihan pemakaian air bersih di PDAM.

Lokasi atau objek penelitian ini berada di Kantor pusat PDAM Tirtauli Kota Pematangsiantar berlokasi di Jalan Porsea No.2, Kelurahan Teladan, Kecamatan Siantar Selatan, Kota Pematangsiantar, Sumatera Utara. Waktu penelitian pada Januari 2021 sampai dengan selesai.

Data yang digunakan dalam penelitian ini adalah data primer dan data sekunder. Sumber data dalam penelitian ini, kata-kata dan tindakan yang diperoleh dari informasi yang terkait dalam penelitian, selanjutnya dokumen atau sumber tertulis lainya merupakan data tambahan.
Metode pengumpulan data dilakukan dengan cara observasi dan dokumentasi. Observasi adalah teknik pengumpulan data yang dilakukan melalui pengamatan, dengan disertai pencatatanpencatatan terhadap keadaan atau perilaku obyek sasaran. Dalam hal ini peneliti melakukan pengamatan langsung berkaitan dengan pemakaian air bersih pada perusahaan daerah minum. Sedangkan dokumentasi adalah suatu cara yang digunakan untuk memperoleh data dan informasi dalam bentuk buku, arsip, dokumen, tulisan angka dan gambar yang berupa laporan serta keterangan yang dapat mendukung penelitian. Dokumentasi digunakan untuk mengumpulkan data kemudian ditelaah.

\section{HASIL \& PEMBAHASAN}

Perusahaan Daerah Air Minum (PDAM) Tirtauli Kota Pematangsiantar adalah badan Usaha Milik Daerah. PDAM Tirtauli merupakan salah satu perusahaan penyedia air minum yang sangat penting bagi masyarakat kota Pematangsiantar. Air yang disalurkan kepada setiap pelanggan setiap bulannya rata-rata $17 \mathrm{~m}^{3} /$ pelanggan. Dan jika setiap harinya dihitung kurang lebih $0,5 \mathrm{~m}^{3} /$ pelanggan.

PDAM Tirttauli Kota Pematangsiantar saat ini melayani 4 (empat) wilayah pelayanan, yakni zona utara yang meliputi wilayah Siantar Martoba dan Siantar Sitalasari, zona selatan yang meliputi wilayah Siantar Selatan, Siantar Timur, Siantar Marihat dan Siantar Marimbun, zona tengah yang meliputi wilayah Siantar Barat dan Siantar utara, dan zona khusus Simalungun yang meliputi Kecamatan Siantar dan Penambean Pane.

\section{Cara Kerja SISKA PDAM Tirtauli}

Sistem komputer akuntansi di PDAM ini membutuhkan software database. Software database yang dipakai adalah DBMS $S Q L$ Server. Software yang digunakan berfungsi untuk mempermudah user membaca data yang tidak bisa dibaca oleh user tersebut. Agar database $S Q L$ Server ini dapat digunakan maka dibutuhkan CRUD dalam pembacaan data. Intinya sistem kegiatan itu akan dibantu oleh CRUD (Creat, Read, Update, Delete) agar dapat mempermudah user dalam pembacaan data. 
SISKA ini juga sangat membantu, karena adanya pendapatan yang bertambah dan berkurang secara dinamis, maka dari itulah diciptakan sistem komputer akuntansi ini.

Diciptakannya aplikasi SISKA ini untuk dapat memberi data kepada manajemen. Jadi proses kegiatan perusahaan harus menciptakan laporan secara baku, yaitu akuntansi baik neraca dan labarugi. Pada saat perusahaan membaca meter maka akan terbentuk rekening, maka rekening tersebut akumulasinya dikatakan dengan DRD (daftar rekening ditagih) itulah yang dikatakan piutang.

Tampilan SISKA untuk pembayaran rekening air dan pembuatan rekening ditunjukkan pada gambar 2 dan gambar 3 berikut:

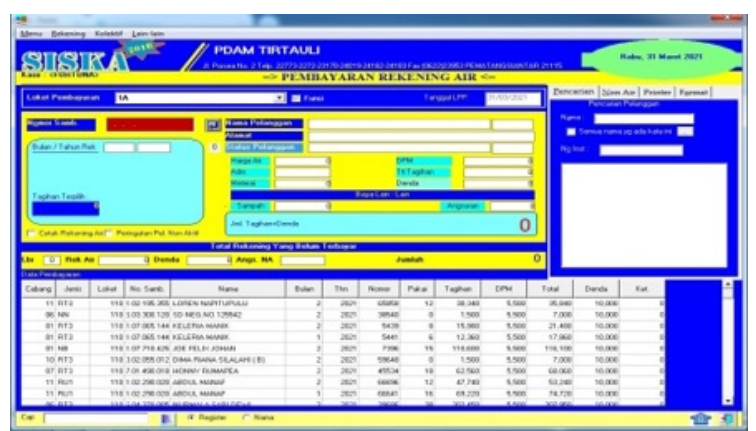

Gambar 2. Tampilan SISKA Pembayaran Rekening Air

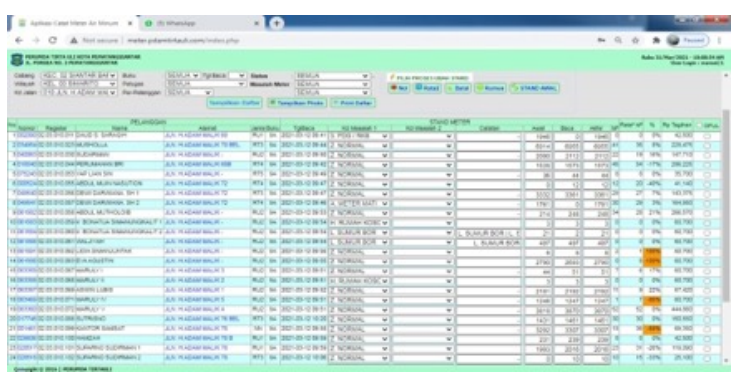

Gambar 3. Tampilan SISKA Pembuatan Rekening

Pada aplikasi ini, perusahaan juga menagih biaya kepada pelanggan untuk memperbaiki pipa, caporit untuk menjernihkan air, membeli pompa, biaya listrik, dan sebagainya.

Sekarang karena kemajuan zaman dan teknologi semakin canggih perusahaan membangun kerjasama dengan orang ketiga yang disebut pihak mitra. Kemampuan pihak mitra inilah yang mengolah semua loket eksternal perusahaan. Jadi pelanggan tidak perlu lagi datang keloket internal perusahaan, karena rekening air sekarang sudah dapat dibayar melalui aplikasi seperti link aja atau juga bisa ke supermarket terdekat seperti Indomaret, Alfamaret dan Alfamidi untuk membayar rekening air, itu sangat membantu pelanggan.

Tetapi jika membayar pada loket ekternal akan dikenakan biaya admin. Jadi proses kerja pihak mitra dengan perusahaan adalah perusahaan memberi data kepada pihak mitra dan perusahaan menerima data dari pihak mitra. Data yang diterima dari loket ekternal dikatakan data 01 , maksudnya pembayarannya hanya lunas atau tidak lunas. Maka setelah itu pihak mitra meminta data untuk membuat kwitansi atau resi penerimaan kepada PDAM.

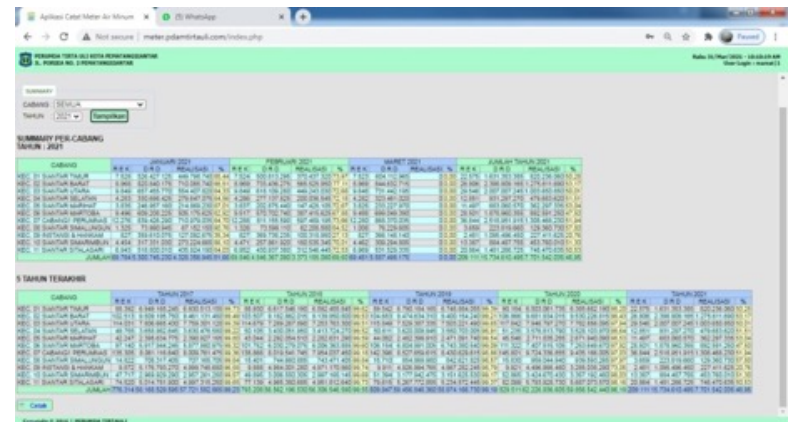

Gambar 4. Tampilan SISKA Akumulasi Output 5 tahun terakhir

Gambar diatas adalah akumulasi output 5 tahun terakhir yang akan dikirimkan kepada bagian manajemen. Gambar diatas juga bertujuan untuk membantu analisis manajemen seperti tindakan-tindakan kedepannya.

\section{Jurnal Rekening}

Semua inputan pembaca meter terakumulasi dijurnal rekening. Hasil proses aplikasi pembuatan rekening dan output yang dikirim kepada manajemen semua tercatat pada jurnal rekening diatas. Jurnal rekening ini juga adalah hasil inputan pembaca meter. Dan dari kegiatan pada aplikasi pembayaran dan aplikasi pembuatan rekening juga terakumulasi di Jurnal Rekening diatas. Jurnal rekening berfungsi untuk menciptakan jurnal penerimaan kas. Tampilan jurnal rekening ditunjukkan dalam gambar 5 berikut: 


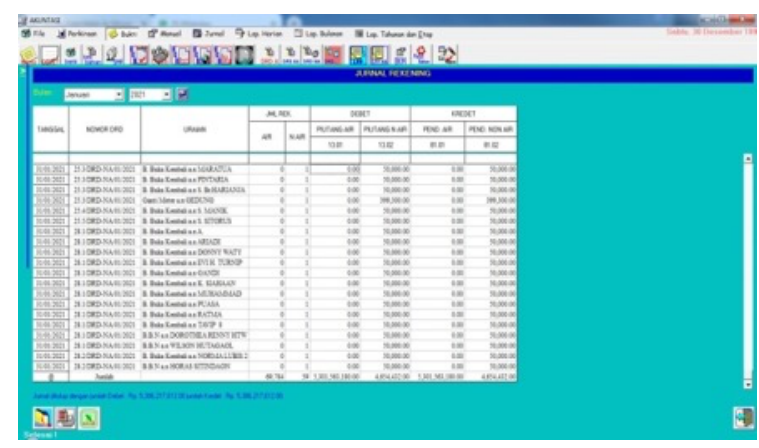

Gambar 5. Tampilan Jurnal Rekening

\section{Jurnal Penerimaan Kas}

Untuk menyusun laba dan rugi maka dibutuhkan jurnal- jurnal yang sudah dijelaskan diatas, serta untuk membuat akumulasi dan mempermudah perhitungannya.

Jurnal penerimaan kas merupakan suatu catatan (jurnal) khusus yang menjadi tempat untuk mencatat transaksi yang berkaitan dengan penerimaan kas. Berikut ini adalah tampilan jurnal penerimaan kas pada PDAM Tirtauli Kota Pematangsiantar:

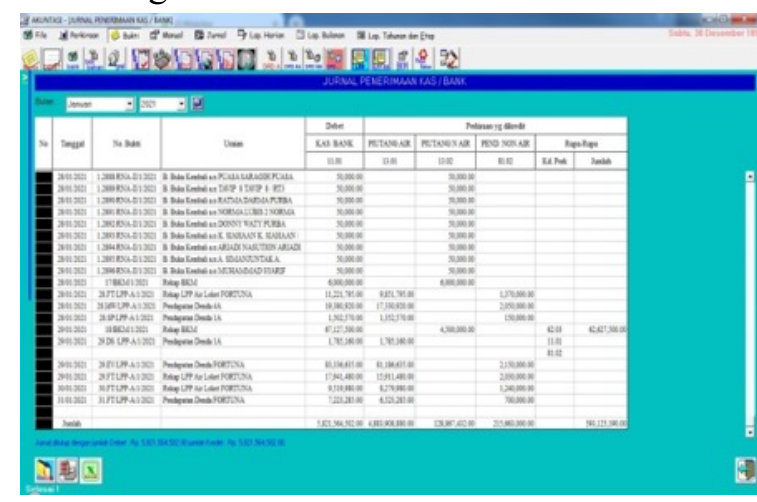

Gambar 6. Tampilan Jurnal Penerimaan Kas

Jurnal penerimaan kas ini digunakan untuk menciptakan laba rugi dan laporan keuangan. Pada jurnal penerimaan kas kita dapat mengetahui berapa pendapatan.

\section{Laba Rugi}

Laba rugi adalah bagian dari laporan keuangan suatu perusahaan yang dihasilkan pada suatu periode akuntansi yang menjabarakan unsur-unsur pendapatan dan beban suatu perusahaan sehingga menghasilkan suatu laba bersih. Gambar dibawah ini menjelaskan bagaimana laba rugi pada PDAM Tirtauli Kota Pematangsiantar:

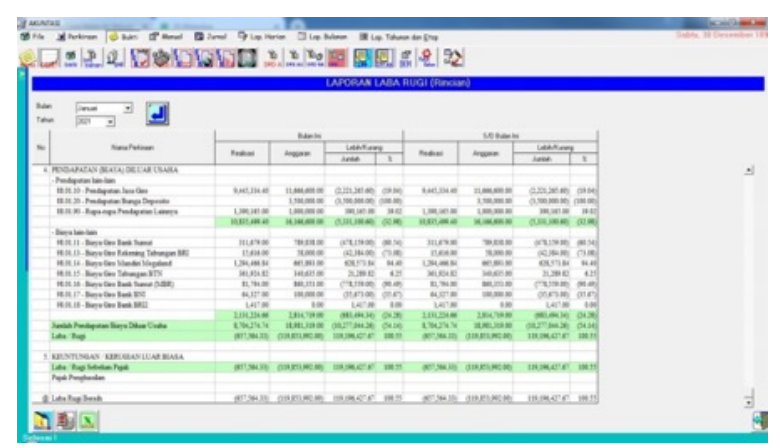

Gambar 7. Tampilan Laporan Laba Rugi

\section{Neraca}

Neraca atau laporan keuangan adalah bagian dari sebuah laporan keuangan suatu entitas yang dihasilkan pada periode akuntansi yang menunjukkan posisi keuangan dari suatu entitas tersebut pada akhir periode tersebut. Gambaran neraca pada PDAM Tirtauli Kota Pematangsiantar dijelaskan pada gambar 8 berikut:

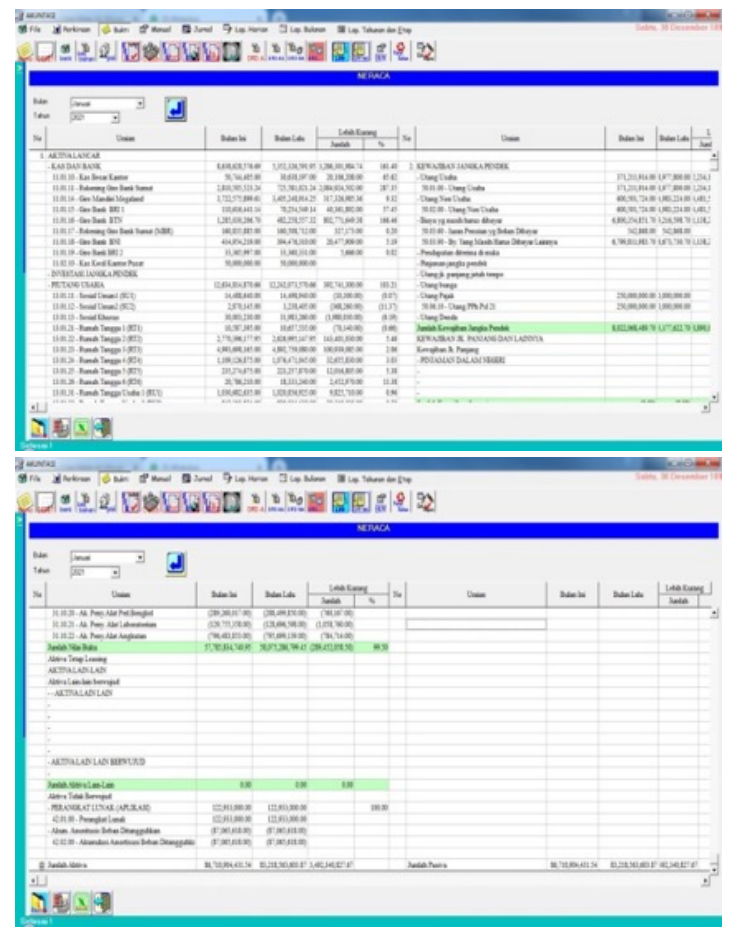

Gambar 8. Tampilan Neraca Keuangan

Gambar diatas menjelaskan bahwa jumlah kasnya berapa. Dan juga dapat diperhatikan bahwa total piutangnya berkurang atau tidak. Pada saat proses rekening dicatat timbul perkiraan piutang pada pendapatan. Pendapatan masuk kedalam laba rugi dan piutang masuk dalam neraca. Itu disebabkan karena adanya piutang belum tertagih. 


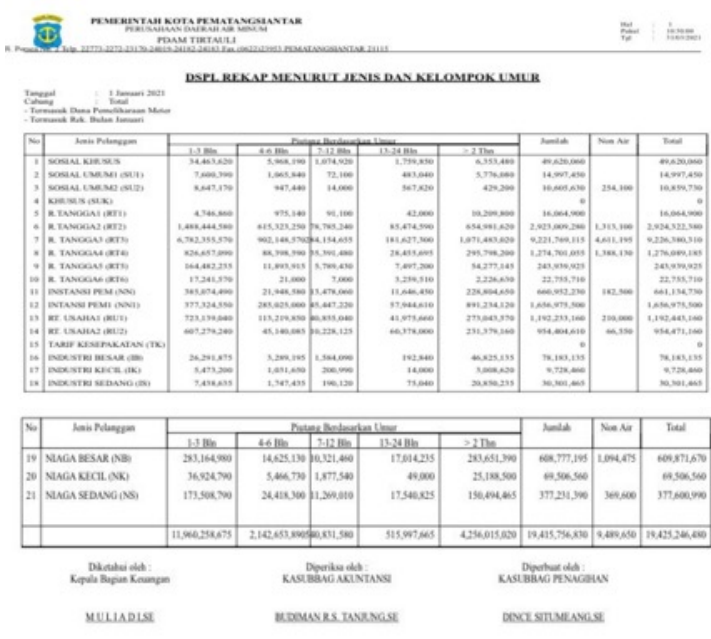

Gambar 9. Laporan Rekap DSPL

\section{Kategori Tarif Air Pelanggan}

Perusahaan Daerah Air Minum (PDAM) Tirtauli Kota Pematangsiantar mengkategorikan tarif air pelanggan seseuai dari golongan dan pemakaian pelanggan.

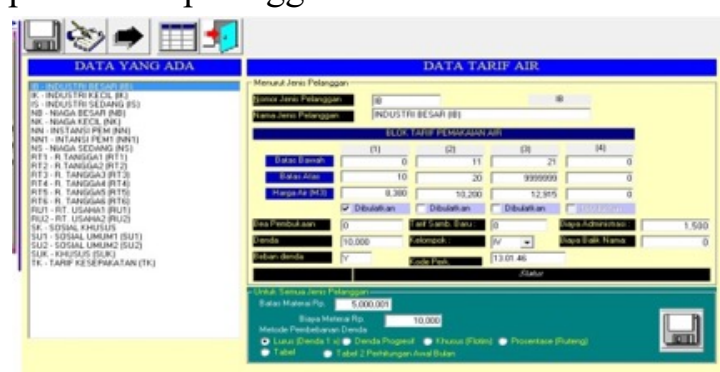

Gambar 10. Tampilan Kategori Pelanggan

\section{Prosedur Pembayaran Rekening Air Pada PDAM Tirtauli}

Prosedur pembayaran rekening air pada PDAM Tirtauli berdasarkan hasil observasi yang dilakukan penulis dijabarkan sebagai berikut:

\section{A. Persyaratan}

Membawa nomor pelanggan atau rekening air bulan sebelumnya.

\section{B. Prosedur}

1. Melalui Kasir Loket Pelayanan:
a. Mengantre di tempat pembayaran
b. Membayar
c. Mendapat bukti pembayaran

2. Melalui ATM

3. Melaui supermarket seperti Indomaret/ Alfamart dan sebagainya.

4. Melalui aplikasi seperti Link aja, dan sebagainya.

5. Tempat pembayaran: a. Loket pembayaran berada di Samping Kantor PDAM Tirtauli.

b. Indomaret, Alfamart dan Alfamidi dengan akun PAM Tirtauli

c. Aplikasi linkaja

\section{Jangka Waktu}

Antrean di loket pembayaran PDAM Tirtauli maksimum 15 menit pada saat jam lancar dan 30 menit pada saat jam pelayanan.

\section{Biaya/Tarif dan Tata Cara Pembayaran}

1. Tarif air minum sesuai golongan pelanggan, berdasarkan klasifikasi tarif pemakaian air minum PDAM Tirtauli

2. Besaran tarif berubah bila terjadi perubahan golongan pelanggan

3. Yang dibayarkan adalah:
a. Biaya Pemeliharaan meter
b. Harga air terpakai
c. Beban tetap (biaya beban tetap bulanan jika pemakaian dibawah dari kebutuhan dasar sebesar $10 \mathrm{~m} 3$ )
d. Denda (bila ada)
e. Angsuran (bila ada)

\section{E. Produk Pelayanan}

1. Bukti pembayaran

2. Laporan penerimaan perhari setiap loket.

\section{Sistem Pembayaran Rekening Air Dengan Data Flow Diagram}

Data Flow Diagram adalah suatu diagram yang menggambarkan aliran data dari sebuah proses atau sistem. DFD juga menyediakan informasi mengenai luaran dan masukan dari setiap entitas dan proses itu sendiri, berikut ini adalah DFD level 0 (diagram konteks) dari hasil observasi peneliti terhadap SISKA yang digunakan di PDAM Tirtauli:

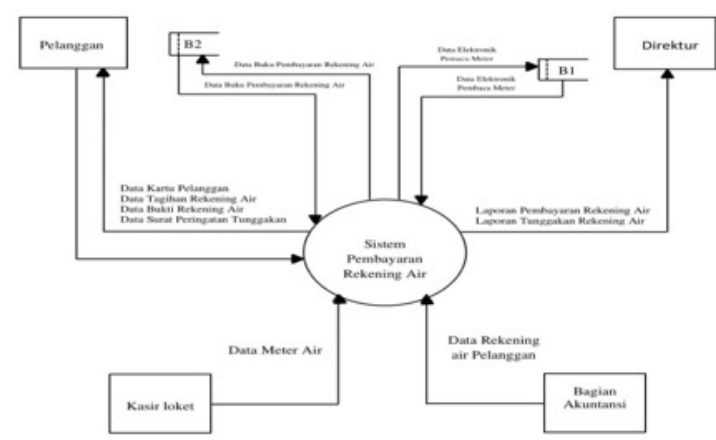

Gambar 11. Diagram Konteks SISKA PDAM Tirtauli 


\section{Flowmap SISKA}

Flowmap adalah paket perangkat lunak yang didedikasikan untuk menganalisis dan menampilkan interaksi atau aliran data. Flowmap juga menunjukkan pergerakan benda dari satu lokasi ke lokasi yang lain. Flowmap dapat digunakan untuk menunjukkan gerakan segala sesuatu, termasuk hal-hal nyata seperti orang, produk, sumber daya alam, cuaca, dan lain sebagainya, serta hal-hal yang tak berwujud seperti kredit. Berikut ini merupakan flowmap SISKA yang berlangsung di PDAM Tirtauli berdasarkan observasi yang dilakukan oleh penulis:

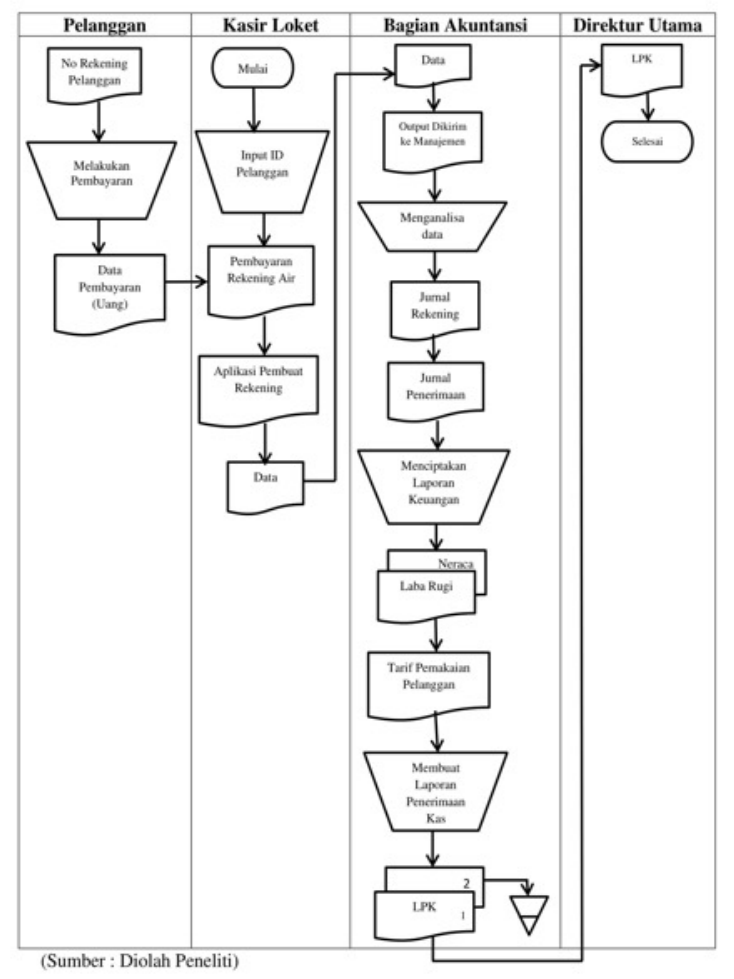

Gambar 12. Flowmap SISKA PDAM Tirtauli

\section{KESIMPULAN}

Berdasarkan hasil penelitian dan pembahasan, maka kesimpulan yang diperoleh dari Analisis Sistem Informasi Akuntansi Penerimaan Biaya Tagihan Pemakaian Air Bersih Pada Perusahaan Daerah Air Minum (PDAM) Tirtauli Kota Pematangsiangtar adalah sebagai berikut:

1. Sistem Informasi Akuntansi yang digunakan pada Perusahaan Daerah Air Minum PDAM Tirtauli Kota Pematangsiantar adalah Sistem Komputer Akuntansi (SISKA). Aplikasi SISKA ini merupakan sistem akuntansi yang mengalami transformasi karena adanya penggunaan database.

2. Pada PDAM Tirtauli ini pelanggan yang menaruh kebutuhannya pada air kurang lebih sebanyak 70.000 pelanggan. Cara kerja SISKA memiliki beberapa tahap. Diawali dengan pembayaran rekening air, selanjutnya data akan dibuat pada aplikasi pembuat rekening. Setelah itu data yang telah dibuat akan dikirimkan ke bagian manajemen. Selanjutnya inputan data yang sudah dikirim akan terakumulasi dijurnal rekening. Dari semua tahap yang sudah dilewati sebelumnya akan terakumulasi pada jurnal penerimaan kas. Semua tahap itu dapat dilakukan pada Sistem Komputer Akuntansi (SISKA).

3. Dengan adanya Sistem Komputer Akuntansi (SISKA) yang dapat dikatakan baik pada PDAM Tirtauli, namun tidak dapat dipungkiri bahwa adanya kendala yang terjadi pada sistem. Seperti contohnya terjadinya kesalahan penginputan data yang dapat menyebabkan SISKA menjadi error. Kendala selanjutnya adalah jaringan yang dapat dikatakan tidak selalu lancar juga dapat menggangu sistem pada PDAM. tidak terjadinya kesalahan pada sistem yang digunakan.

\section{DAFTAR PUSTAKA}

Anggraeni. (2017). Pengantar Sistem Informasi. Yogyakarta: Andi Offset.

Arisqua, R. F. V., Isharijadi, \& Wijaya, A. L. (2017). Analisis sistem informasi akuntansi penerimaan dan pengeluaran kas guna efektivitas pengendalian intern pada PDAM Tirta Dharma Parabaya Kabupaten Madiun. FIPA: Forum Ilmiah Pendidikan Akuntansi (Vol. 5, No. 1).

Diana Anastasia \& Setiawati. (2011). Sistem Informasi Akuntansi, Perancangan, Prosedur dan Penerapan (Edisi 1). Yogyakarta: Andi Offset.

Hasanah, U. (2013). Analisis sistem informasi akuntansi penerimaan kas jasa rawat inap: Studi kasus pada RSUD DR. Saiful Anwar Malang Malang. Universitas Islam Negeri Maulana Malik Ibrahim.

Kadir Abdul. (2014). Pengendalian Sistem Informasi (Ed. Revisi). Yogyakarta: Alfabeta. 
Krismaji. (2015). Sistem Informasi Akuntansi

(Edisi 4). Yogyakarta: Sekolah Tinggi Ilmu Manajemen YKPN.

Mulyadi. (2016a). Sistem Akuntansi. Jakarta: Salemba Empat.

Mulyadi. (2016b). Sistem Informasi Akuntansi. Jakarta: Salemba Empat.

Romney. (2015). Sistem Informasi Akuntansi (Edisi 13; alihbahasa: Kikin Sakinah Nur Safira dan Novita Puspasari, Ed.). Jakarta: Salemba Empat.

Romney, M. B., \& Steinbart, P. J. (2018). Accounting Information Systems (Edisi 14). New Jersey: New Jersey: Pearson Education, Inc.

Sinambela, D. R., Purba, D. H. P., \& Jamaluddin. (2020). Evaluasi Penerapan Sistem Informasi Akuntansi Atas Pendapatan Sewa Kamar Hotel Secara Online Pada Grand Sakura Hotel Medan. Jurnal Teknologi Dan Ilmu Komputer Prima (JUTIKOMP), 3(2), 489-495. https://doi.org/10.34012/jutikomp.v\%25vi $\% 25 i .1377$

Sujarweni V. Wiratna. (2015). Sistem Akuntansi. Pustaka Baru Press.

Susanto Azhar. (2013). Sistem Informasi Akuntansi - Struktur Pengendalian, Resiko \& Pengembangan (Edisi 1). Bandung: Lingga Jaya.

Susanto Azhar. (2017). Sistem Informasi Akuntansi - Pemahaman Konsep Secara Terpadu (Edisi 1). Bandung: Lingga Jaya. 